\title{
Resilient cities, user-driven planning, and open data policy AUTHORS
}

Paul Burton ${ }^{a}$

Anne Tiernan ${ }^{b}$

Malcolm Wolskic

Lex Drennan ${ }^{d}$

Lochlan Morrissey e

\section{AUTHOR BIOS}

a Cities Research Institute, Griffith University

p.burton@griffith.edu.au

Paul Burton is Professor of Urban Management and Planning and Director of the Cities Research Institute at Griffith University

${ }^{b}$ Griffith Business School, Griffith University

a.tiernan@griffith.edu.au

Anne Tiernan is Professor of Public Policy and Dean (Engagement) of the Griffith Business School

${ }^{c}$ eResearch Services, Griffith University

m.wolski@griffith.edu.au

Malcolm Wolski is Director of eResearch Services at Griffith University.

d Policy Innovation Hub, Griffith University

I.drennan@griffith.edu.au

Lex Drennan is an Adjunct Industry Fellow at the Policy Innovation Hub, Griffith University.

e Policy Innovation Hub, Griffith University

I.morrissey@griffith.edu.au

Lochlan Morrissey is a Postdoctoral Research Fellow at the Policy Innovation Hub, Griffith University.

\section{ABSTRACT}

We present a framework for user-driven planning that links disaster management policy and legislation, open data, and individual households and residents, focusing on Queensland. Relating open data sets to a practical model of planning reveals two major problems with currently available data. First, they are fragmented, and so multiple datasets maintained by different agencies must be consulted for a user to be able to obtain a holistic view of her risk. Second, use of the data generally requires some expertise in data analysis. We propose that narrative policy analysis may ameliorate this problem, by presenting data (a) in amalgamated platforms that combine data of various hazards and risks; and (b) so that the user is positioned in a 'resilience narrative', and her disaster risk is more reality understood.

\section{KEYWORDS}

disaster planning; open data; amalgamated data platforms; policy narratives

\section{HIGHLIGHTS}

- a user-driven model for disaster planning;

- proposal for an amalgamated approach to open data sources;

- narrative-based communication of disaster risk;

- alignment of subjective and objective risk through open data platform design. 


\section{TABLE OF CONTENTS}

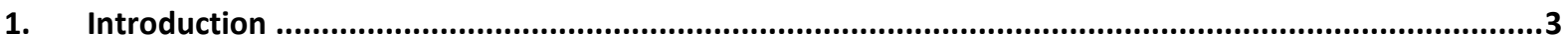

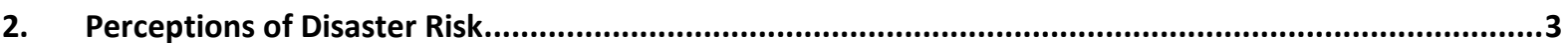

3. Disaster management planning and the user-driven turn ..........................................................4

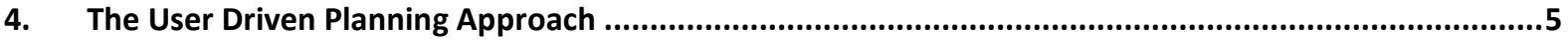

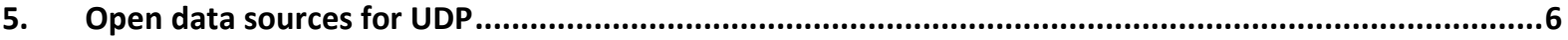

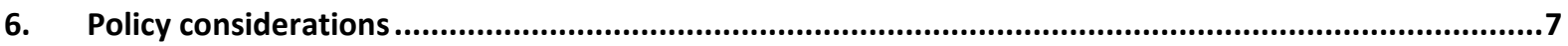

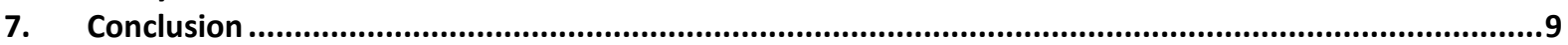

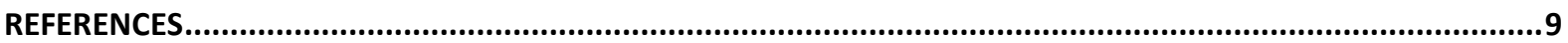

\section{LIST OF FIGURES}

Figure 1: Steps in the Traditional Planning Process.

Figure 2: Steps in a User-Driven Planning Process.

\section{LIST OF ABBREVIATIONS \\ User Driven Planning (UDP)}

Note regarding data references: The editors encourage all authors to deposit their data sets in a data repository or data store - and cite and link to the data set in your chapter. If your dataset is not currently published, the editors are offering the option to add the data set(s) to CityData:

https://citydata.be.unsw.edu.au. This may assist you if you'd like to publish your data with a digital object identifier - to give it bibliographic identity. You will be referenced when this data set is used. If you'd like to have your data hosted here, please contact the editors to submit a proposal. 


\title{
1. INTRODUCTION
}

The population of Australia is predominantly urban and coastal. Two thirds of Australians living in capital city statistical areas with growth rates expected to continue to rise (Australian Bureau of Statistics, 2017). As more people are concentrated into a smaller geographic area, the effects of disaster events on these areas are likely to become more extreme and disruptive (Deloitte Access Economics, 2013, 2016). Furthermore, the number of disaster events and the costs associated with disaster events is expected to increase into the 21st century (Cowan et al., 2014; Purich et al., 2014; Zheng, Westra, \& Leonard, 2015). Successful adaptive cities will be those that support the resilience of their residents. Resilience is understood in this paper as the capacity of a system to adapt to the new situation that is ushered in by a disaster event (Tierney, 2012).

Resilience is enhanced not only through risk-sensitive construction of the built environment, but also importantly through the promotion of social capital and cohesion (Aida, Kawachi, Subramanian, \& Kondo, 2013; Aldrich \& Meyer, 2015; Henly-Shepard et al., 2015; Kapucu, Hawkins, \& Rivera, 2013; Shaw, 2013). The resilience of cities is significantly influenced by the strength of their economy. Small to medium businesses, in particular, play a critical role in building resilience and applying these resources in the aftermath of disasters (Drennan, McGowan, \& Tiernan, 2016; Tiernan, McGowan, \& Drennan, 2013).

In this chapter, we present a framework for user-driven planning that links disaster management policy and legislation of various levels of government, open data produced by various agencies, and businesses. Disasters are defined with reference to government policy, using the definition provided by the National Disaster Relief and Recovery Arrangements (Attorney-General's Department, 2012, pp. 5-6). Accordingly, a disaster is "a natural disaster or terrorist event" where a natural disaster is defined as:

\begin{abstract}
"a serious disruption to a community or region caused by the impact of a naturally occurring rapid onset event that threatens or causes death, injury or damage to property or the environment and that requires significant and coordinated multi-agency and community response, and is one, or a combination of, the following: a) bushfire; b) earthquake; c) flood; d) storm; e) cyclone; f) storm surge; g) landslide; h) tsunami; i) meteorite strike; j) tornado" (Attorney-General's Department, 2012, pp. 5-6) .
\end{abstract}

By applying the principles of user-driven planning (UDP), open data on disaster risk can be contextualised to the local level. This allows objective measures of risk to be communicated meaningfully to local business owners. Such an approach can enable businesses to apply data to understand their risk environment, assess their individual exposure and build adaptive resilience capabilities without top-down command and control from government. Open-data has the potential to bridge governments' objective risk perspectives with local, subjective interpretations.

Building on this model of user-driven planning, we explore policy implications in the areas of disaster management and open data specifically with respect to Queensland, and Queensland governmentadministered data. The Queensland government is very proactive in their approach to Open Data, with each Department having its own Open Data Strategy. We address some ways that UDP might be improved through policy initiatives, including: more consistent, usable datasets; formulating standard measures that target specific hazards and specific properties or geographic areas; and committing funds to building a platform for residents to easily assess their own risk, and for UDP at the household level. These measures provide a means of increasing social capital by using residents' and organisations' local knowledge in the disaster management process, leading to more adaptive and resilient cities than is possible under current, top-down approaches to disaster management.

\section{PERCEPTIONS OF DISASTER RISK}


Broadly speaking, risk can either be considered objectively or subjectively (Hansson, 2010). In the objective approach, taken by the International Standard on Risk Management and embedded in Australian government policy via the National Emergency Risk Assessment Guidelines, risks are external, knowable and discretely quantifiable (Emergency Management Australia, 2015; ISO, 2009). From this perspective, government risk assessments, at their most basic, involve estimating the likelihood of an event, estimating consequences of that event and implementing appropriate mitigation measures on that basis (Emergency Management Australia, 2004). Unstated in this approach is the presumption that the communities impacted by these risks, and attendant policy prescriptions, apply the same analytic frame to understanding their risk environment (Drennan, 2017).

However, extensive research has shown that individuals, and by extension communities, view risk through a subjective lens (Henwood, Pidgeon, Parkhill, \& Simmons, 2010; Ho, Shaw, Lin, \& Chiu, 2008; Paton, 2005; Paton, Smith, Daly, \& Johnston, 2008). In this subjective perspective, the individual considers their perception of likelihood and balances it against estimates of her ability to cope with this event. Furthermore, factors such as risk sensitivity and beliefs about the role of government impact how individuals or communities may act to mitigate risks (Alkon, 2004; Lindell \& Whitney, 2000). These factors comprise the risk narrative of individuals, businesses and communities and often results in very different beliefs about risk levels and appropriate mitigation measures to that recommended in government policy (Corvellec, 2011; Drennan, 2017; Menapace, Colson, \& Raffaelli, 2012; Sjöberg, 2000).

\section{DISASTER MANAGEMENT PLANNING AND THE USER-DRIVEN TURN}

In this section, we discuss Disaster Management (DM) planning and its paradigm of top-down management. A model of user driven planning is proposed to bridge the top-down, objective risk assessment paradigm, with a local and individualised subjective interpretation of risk. We argue that open data sets are the mechanism by which these two perspectives can be bridged as a point of common understanding.

DM evolved from civil defence and it consequently operates in a paradigm of top-down management (Clarke, 1999; W. Waugh, 2006). Yet, "the response to natural disasters is, in large measure, an ad hoc affair involving organized nongovernmental actors, governmental actors, and emergent groups that often become well organized and long lived. No one can ever have complete control; it is not possible to fully command attention or to compel compliance" (William Waugh \& Streib, 2006, p. 138). This approach has received sustained criticism from scholars as it does not provide the emphasis on coordination needed to address the complexity and multi-actor nature of crises (Alpaslan, Green, \& Mitroff, 2009; Boin, 't Hart, Stern, \& Sundelius, 2005; Goldsmith \& Eggers, 2003; William Waugh, 2009; Wise \& Nader, 2002). Instead, they call for approaches that emphasise relationships, decentralisation, collaborative networks and a participatory approach to decision-making (Alpaslan et al., 2009; Boin \& 't Hart, 2010; Comfort \& Kapucu, 2006; Kapucu \& Garayev, 2011; Wise \& Nader, 2002).

The standard approach to building disaster management capability is to document the system, then practice increasingly complex elements of the system (Clarke, 1999; ISO, 2014). This generally progresses through training individuals, training teams, to exercising one team then multiple teams simultaneously. The Plan-Do-Check-Act cycle that underpins the Business Continuity Management Systems standard embodies this approach (ISO, 2014).

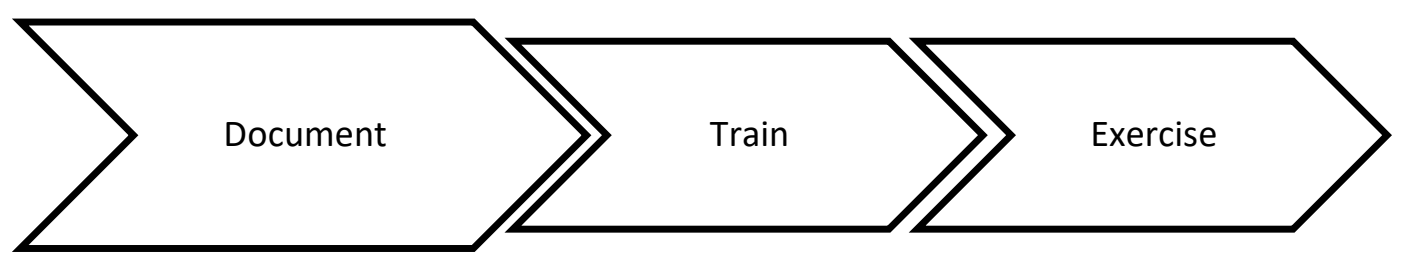


This approach follows logically from the expert-driven approach to disaster management planning which sees appointed experts extracting knowledge from organisational members, developing products and then teaching the organization how to use these outputs. The top-down philosophy of disaster response extends into the approach to planning which is largely characterized by an expertdriven style of planning which privileges technical expertise and tends to discount local knowledge (Clarke, 1999).

Debate over the role of experts versus participants arises commonly in the urban planning sector because "Planning is a social process as well as a technical one" (Larkham \& Lilley, 2012, p. 648). Numerous authors argue that expert-driven, top-down planning frequently fails to engage communities or produce plans which engender widespread community support (Arnstein, 1969; Fiskaa, 2005; Jacobs, 1961; Larkham \& Lilley, 2012). In her seminal work, 'The Death and Life of Great American Cities' (Jacobs, 1961), Jacobs takes explicit aim at the expert-driven planning approach as it fails to understand the lived experience of communities and their interactions with their physical environment.

This perspective is similarly embraced in the field of participatory governance, where responsibility and authority for problem solving is devolved from central governments to local communities.

Participatory governance enables "those most directly affected by targeted problems...to apply their knowledge, intelligence and interest to the formulation of solutions" (Fung \& Wright, 2001, p. 18). This approach leverages local knowledge and intentionally makes the subjective perspective part of the policy solution. In this approach, the role of experts in this approach becomes to "facilitate popular deliberative decision making" and "to leverage synergies between professional and citizen insights rather than pre-empt citizen input"(Fung \& Wright, 2001, p. 19).

\section{THE USER DRIVEN PLANNING APPROACH}

Building on the traditions of urban planning and participatory governance, we propose a user-driven approach to disaster management that seeks to emphasise the role of the participant in planning whilst retaining the expertise of the disaster management professional. By integrating local, subjective understandings of risk with government objective assessments, UDP has the potential to bridge these perspectives and enable businesses to build their disaster resilience capabilities.

UDP makes two critical assumptions:

i. $\quad$ the user knows itself and its business best; and

ii. the user's disaster management process is intuitively clear to that user, but not necessarily to outside observers.

In essence, these assumptions privilege the knowledge held by every-day employees of an organisation. They also reflect the understanding that under pressure people and organisations default to what they know. This approach reverses the first two steps in the planning process on the basis of the assumptions outlined.

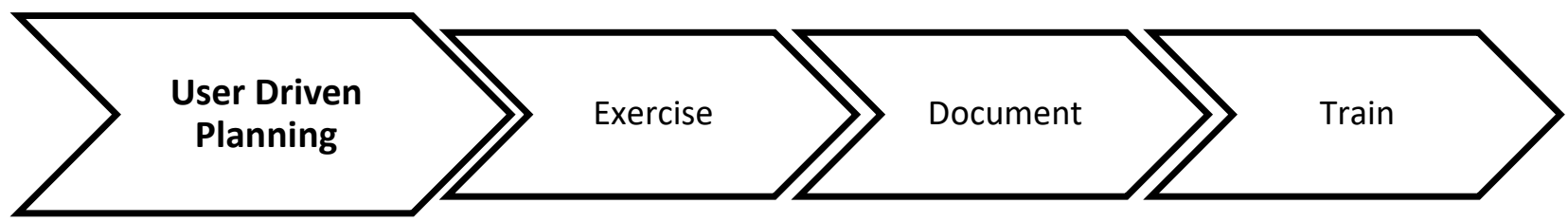

Figure 2: Steps in a User-Driven Planning Process. 
UDP is a 'bottom-up' planning approach that captures the 'as-is' in the organisation response to a major business interruption. Contrasting with the traditional disaster management process, in UDP, the planning process commences by conducting a disaster management exercise without training or preparing participants. This allows the observation and documentation of the 'as-is' organisational approach to disaster management. The observed process is then shaped by best practice planning approaches that seek to enhance the effectiveness of the organisation's instinctive response and embed local knowledge, rather than dictate an entirely new system. The benefits of this approach are that it leverages day-to-day organisational practice, lessens the training liability required to maintain organisational capability, increases the utility of disaster management plans and provides a framework that is instinctively understood by its users.

Throughout the process of the exploratory exercise, debriefing, followed by a plan review exercise, participants have numerous opportunities to identify where the organisation needs to build capability. This feedback forms the basis of a capability development and maintenance program that reflects participant understanding of their needs. Making these activities short, regular and targeted moves the program away from repetitive training of the plan to building the complex skill sets necessary to effectively manage an incident. The exercising component is essential: "Regular simulation exercises nurture awareness of crisis management complexities, hone decision-making skills, and allow members of the response network to get to know, understand and respect each other. Not having this is one of the principal causes of crisis response failures" (Boin \& "t Hart, 2010, p. 368).

\section{OPEN DATA SOURCES FOR UDP}

In this section, we identify specific, open datasets that may be used to improve the quality of plans devised using the UDP approach, and suggest ways that datasets might be extended to provide more functionality for UDP. In particular, we focus on datasets that are produced by Queensland governments. Queensland has become a leader in Australian open data policy, with each Department and statutory body of the state government required to produce an open data strategy. ${ }^{1}$ Accessing Queensland's open data is simple for even inexperienced users: the Queensland government provides a centralised search for its datasets that spans the departments and statutory bodies at https://data.qld.gov.au.

There are a number of open datasets that may be used to facilitate UDP. Data of historical disaster events is useful for UDP in that it provides a point of comparison for potential disaster events with those that are in the organisation's memory. The following table summarises some datasets that we propose are useful for UDP.

\begin{tabular}{|c|c|c|c|}
\hline Title & Description & Use for UDP & URL \\
\hline $\begin{array}{l}\text { Flood extent maps } \\
1974 \text { (State of } \\
\text { Queensland, } \\
\text { 2012) }\end{array}$ & $\begin{array}{l}\text { Spatial data of the } \\
\text { extent of the } \\
\text { Brisbane and } \\
\text { Ipswich floods of } \\
1974 \text {. }\end{array}$ & \multirow{2}{*}{$\begin{array}{l}\text { Afford organisations a means of } \\
\text { observing how their assets might be } \\
\text { affected in a similar event, and to } \\
\text { plan accordingly. A potential } \\
\text { drawback of these datasets is that } \\
\text { the degree of similarity of disaster } \\
\text { events is highly uncertain. }\end{array}$} & $\begin{array}{l}\text { https://data.qld.gov.au/dataset/flood- } \\
\text { extent-series/resource/a94a60b0- } \\
\text { 76ed-424b-a52b-b307e20af224 }\end{array}$ \\
\hline $\begin{array}{l}\text { Flood extent maps } \\
2011 \text { (State of } \\
\text { Queensland, } \\
\text { 2015) }\end{array}$ & $\begin{array}{l}\text { Spatial data of the } \\
\text { extent of the } \\
\text { Queensland floods } \\
\text { of } 2011 .\end{array}$ & & $\begin{array}{l}\text { https://data.qld.gov.au/dataset/flood- } \\
\text { extent-series/resource/4c687b12- } \\
2666-4293-94 \text { c8-0fbf71346fc1 }\end{array}$ \\
\hline $\begin{array}{l}\text { Gold Coast City } \\
\text { Plan interactive } \\
\text { map (City of Gold } \\
\text { Coast, 2017) }\end{array}$ & $\begin{array}{l}\text { An amalgamation of } \\
\text { a number of spatial } \\
\text { datasets that } \\
\text { present a } \\
\text { generalised risk } \\
\text { profiles based on } \\
\text { prior disasters. }\end{array}$ & $\begin{array}{l}\text { Provides organisations with spatial } \\
\text { representations of multiple of } \\
\text { different hazards, which allows them } \\
\text { to account for these hazards in the } \\
\text { one plan. However, these lack the } \\
\text { narrative cogency of a } \\
\text { representation of a past disaster } \\
\text { event. }\end{array}$ & $\begin{array}{l}\text { http://cityplanmaps.goldcoast.qld.gov. } \\
\text { au/CityPlan/ }\end{array}$ \\
\hline
\end{tabular}

\footnotetext{
${ }^{1}$ As of the time of writing, the full list of these strategies is available at https://data.qld.gov.au/article/department-strategies.
} 


\begin{tabular}{|c|c|c|c|}
\hline $\begin{array}{l}\text { Interactive road } \\
\text { conditions map } \\
\text { (Moreton Bay } \\
\text { Regional Council, } \\
\text { 2017) }\end{array}$ & $\begin{array}{l}\text { A near-real time } \\
\text { map that shows } \\
\text { road closures, } \\
\text { reported traffic } \\
\text { accidents, and so } \\
\text { on. It is confined to } \\
\text { the Moreton Bay } \\
\text { LGA. }\end{array}$ & \multirow{3}{*}{$\begin{array}{l}\text { Provide real-time data that can be } \\
\text { incorporated as part of the UDP } \\
\text { process, and that can be used to } \\
\text { inform the enactment of a user's } \\
\text { disaster management plan in the } \\
\text { event of a disaster. }\end{array}$} & $\begin{array}{l}\text { https://www.moretonbay.qld.gov.au/m } \\
\text { aps-disaster.aspx }\end{array}$ \\
\hline $\begin{array}{l}\text { QLDTraffic (State } \\
\text { of Queensland } \\
\text { (Department of } \\
\text { Main Roads and } \\
\text { Transport), 2017b) }\end{array}$ & $\begin{array}{l}\text { A near-real time } \\
\text { map that shows } \\
\text { road closures, } \\
\text { reported traffic } \\
\text { accidents, and so } \\
\text { on, across } \\
\text { Queensland }\end{array}$ & & https://qldtraffic.qld.gov.au/ \\
\hline $\begin{array}{l}\text { Near real-time tide } \\
\text { levels (State of } \\
\text { Queensland } \\
\text { (Department of } \\
\text { Main Roads and } \\
\text { Transport), 2017a) }\end{array}$ & $\begin{array}{l}\text { Numeric data of tide } \\
\text { levels taken in near- } \\
\text { real time at } \\
\text { Gladstone, } \\
\text { Queensland. }\end{array}$ & & $\begin{array}{l}\text { https://data.qld.gov.au/dataset/gladsto } \\
\text { ne-tide-gauge-near-real-time-data }\end{array}$ \\
\hline
\end{tabular}

The resources identified above represent potential datasets that can be used for UDP to bridge the objective risk perspective of governments and the subjective application by the user. Although these datasets are easily accessible to the non-expert, two problems are readily apparent in their application. First, the data themselves are fragmented, and held by a number of different custodians. While there is a centralised search function, users are required to download each dataset individually. This fact means that the data are semantically incompatible, and therefore collation of the data becomes more challenging. For instance, tide level data and flood extent data represent a phenomenon that is interrelated, and mutually reinforce a user's risk, yet these are available only in separate datasets. Second, many of the datasets are presented in files that require some degree of familiarity with and expertise in working with data of this kind. For instance, the flood extent maps must be downloaded and opened on a user's machine. Furthermore, each flood dataset must be opened separately, leading to a lack of continuity between the datasets.

We argue that these two problems combine to weaken the usefulness of the available data for the purposes of UDP. These both subtract from the user understanding the relevance of the data to her own situation. Instead of presenting a unified, coherent picture of the user's risk with respect to a number of hazards, the user is only able to view data with respect to specific risks, and with specific instances of these risks. Furthermore, the ability to do so assumes the user can locate the data and then apply that data it in the manner intended by the data provider. Consequently, despite the potential of open data to support building business resilience, and the potential of its application through UDP, the fragmentation of datasets impedes the process of bridging the objective/subjective risk perception divide.

\section{POLICY CONSIDERATIONS}

Government entities play a leading role in designing and delivering open platforms that ingest, collate, and combine a number of potentially disparate datasets. Since these datasets belong largely to government entities, public policy considerations are centrally important to successfully enabling and promoting user driven disaster management planning. In this section we outline how governments can improve the utility of open data sets for UDP, thereby enhancing the preparedness of businesses to face a broad spectrum of natural hazard risks.

In essence, government policy should seek to ensure that combined data platforms are designed to provide a user with a more complete picture of her disaster risk and the quality of her resilience. For instance, Disaster Hub-a website ${ }^{2}$ prepared by the Local Government Association Queensland-

\footnotetext{
${ }^{2}$ See http://www.disasterhub.com.au/.
} 
collects data from a number of sources, and provides interactive maps on which various risks are represented geographically. It also provides real-time data on rainfall at rain gauges across the Local Government Area, up-to-date locations of car accidents, power outages, strong weather warnings issued by the Bureau of Meteorology, and it provides lists of school closures, social media posts, evacuation centres, and so on. These kinds of platforms provide data that allows for plans to be devised at the individual, household, or organisation level.

To enhance the usefulness of these data platforms, careful consideration should be given to two aspects of their design. First, the data should be semantically commensurate. That is, the data should, as much as possible, represent kinds of measurement that can be understood. For instance, representing tide levels in a river system and in a bay may differ greatly if they are represented purely in numbers. This difference reduces the intelligibility of the data. If this same data were presented, for instance, pictorially, so that the extent of the tide change was represented on a map, then a commonality in the measures emerges for the non-expert user. This consideration may also render data that are represented by different measures intelligible to non-expert users. For instance, interactions between river level measurements and rain gauge measurements by themselves are not necessarily meaningful when only the raw measurements are viewed by a non-expert. But if the combined effect of the rain measurement and the river measurement is modelled and presented pictorially, then a more complete picture of a potential hazard emerges.

As we have noted, UDP is undertaken by users who are not necessarily domain experts. Therefore, the data on the platforms should be presented in a way that does not assume such expertise. In particular, the data should be presented in a way that is sensitive to the subjective risk assessment of the users, and that do not assume only objective risk measurements.

A successful amalgamated data platform will attempt to align the user's subjective risk and her objective risk as closely as possible. We argue that this may be achieved by leveraging findings of narrative policy analysis (see, for instance, Hampton, 2009; Jones \& McBeth, 2010; Roe, 1994). Narrative policy analysts examine the narrative strategies that policymakers use to communicate their policy ideas, and that activists use to shift the policy agenda. The effects of a narrative on the perception of a particular event and its relation to policymaking can be considerable. As Fischer and Forester (1993, p. 44) point out,

whether or not a situation is perceived as a political problem depends on the narrative in which it is discussed. To be sure, large groups of dead trees as such are not a social construct; the point is how one makes sense of dead trees. ... One may see dead trees as the product of natural stress caused by drought, cold, or wind, or one may see them as victims of pollution ... [thereby constituting] a political problem.

McComas and Shanahan (1999) document the use of narratives in US climate policy, and the effects of these narratives in reaching the attention of policymakers, McBeth, Shanahan, Arnell, and Hathaway (2007) illustrate the ways in which environmental activists alter their narrative strategies to suit the political and policy environment, and Hampton $(2005,2009)$ argues that policy narratives may be used to increase public participation in policymaking.

An example of a concrete narrative strategy for a data platform is to include a user's risk and resilience in an historical perspective. For instance, geographically representing the extent of a previous disaster allows a user to connect her memory of the event to potential future events. Furthermore, coordinating a risk in a chain of causal events-for instance, the effects of the tides on the flooding of tributaries that run through communities that are further away from the coast-will serve to allow the user to position themselves in a larger risk and resilience narrative. Government policy which recognises the power of subjective risk narratives and is mindful of how data is presented within this narrative frame will allow for greater public participation by increasing the legibility and comprehensibility of the data for citizens. 


\section{CONCLUSION}

Small to medium businesses play a critical role in building and sustaining the resilience of cities; their contribution to strong economies is vital. Similarly, their ability to withstand disasters and recover quickly is essential to broader community resilience. We have outlined how businesses can use open data to build their resilience. The model of user driven planning leverages an extensive tradition of participant leadership and problem solving in the domains of urban planning and participatory governance. In this chapter we have sought to integrate the approach of subjective user led planning with hazard risk assessments using open-data as the bridge to connect these world views. We have provided a novel approach to the challenge of building resilient cities which will benefit from further research to understand how this approach can work in practice.

In more immediate terms, our analysis of the user experience interacting with current data sets points to where governments can enhance open data policy to benefit users through enhanced accessibility and utility of these data. The Queensland Government has made significant progress in making such data available to the public. Policy and platforms which consider usability from a risk narrative perspective will enhance the Government's efforts to promote disaster resilient communities. Queensland is exposed to numerous, and increasingly severe natural hazards; leveraging open data to build the resilience of cities provides an important pathway to face the challenges of its rapidly changing climate.

\section{REFERENCES}

Aida, J., Kawachi, I., Subramanian, S. V., \& Kondo, K. (2013). Disaster, Social Capital and Health. In I. Kawachi, S. Takao, \& S. S.V. (Eds.), Global Perspectives on Social Capital and Health (pp. 167-188).

Aldrich, D. P., \& Meyer, M. A. (2015). Social Capital and Community Resilience. American Behavioral Scientist, 59(2), 254-269. doi:10.1177/0002764214550299

Alkon, A. H. (2004). Place Stories and Consequences: Heritage Narratives and the Control of Erosion on Lake County, California, Vineyards. Organization \& Environment, 17(2), 145-169.

Alpaslan, C. M., Green, S. E., \& Mitroff, I. I. (2009). Corporate Governance in the Context of Crises: Towards a Stakeholder Theory of Crisis Management. Journal of Contingencies and Crisis Management, 17(1), 38-49. doi:10.1111/j.1468-5973.2009.00555.x

Arnstein, S. R. (1969). A Ladder Of Citizen Participation. Journal of the American Institute of Planners, 35(4), 216-224. doi:10.1080/01944366908977225

Attorney-General's Department. (2012). National Disaster Relief and Recovery Arrangements: Determination 2012, version 2.0. Retrieved from Canberra:

Australian Bureau of Statistics. (2017). Regional Population Growth, Australia, 2015-16.

Boin, A., \& 't Hart, P. (2010). Organising for effective emergency management: lessons from research. The Australian Journal of Public Administration, 69(4), 357-371.

Boin, A., 't Hart, P., Stern, E., \& Sundelius, B. (2005). The politics of crisis management: public leadership under pressure. Cambridge: Cambridge University Press.

Clarke, L. (1999). Mission Improbable: Using Fantasy Documents to Tame Disaster. Chicago and London: University of Chicago Press.

Comfort, L. K., \& Kapucu, N. (2006). Inter-organizational coordination in extreme events: The World Trade Center attacks, September 11, 2001. Natural Hazards, 39(2), 309-327. doi:10.1007/s11069-006-0030-x

Corvellec, H. (2011). The Narrative Structure of Risk Accounts. Risk Managemen, 13(3), 101-121. doi:10.1057/rm.2011.5

Cowan, T., Purich, A., Perkins, S., Pezza, A., Boschat, G., \& Sadler, K. (2014). More frequent, longer, and hotter heat waves for Australia in the twenty-first century. Journal of Climate, 27(15), $5851-5871$.

Deloitte Access Economics. (2013). Building our nation's resilience to natural disasters. Sydney: Deloitte Access Economics.

Deloitte Access Economics. (2016). The economic cost of the social impact of natural disasters. Sydney: Deloitte Access Economics. 
Drennan, L. (2017). Community Narratives of Disaster Risk and Resilience: Implications for Government Policy. Australian Journal of Public Administration, O(0).

Drennan, L., McGowan, J., \& Tiernan, A. (2016). Integrating Recovery within a Resilience Framework: Empirical Insights and Policy Implications from Regional Australia. Politics and Governance, 4(4), 74. doi:10.17645/pag.v4i4.741

Emergency Management Australia. (2004). Emergency Management in Australia: Concepts and Principles. Canberra: Commonwealth of Australia.

Emergency Management Australia. (2015). National Emergency Risk Assessment Guidelines (NERAG) Handbook. Canberra: Commonwealth of Australia Retrieved from https://knowledge.aidr.org.au/resources/handbook-10-national-emergency-risk-assessmentguidelines/.

Fischer, F., \& Forester, J. (1993). The argumentative turn in policy analysis and planning: Duke University Press.

Fiskaa, H. (2005). Past and future for public participation in Norwegian physical planning. European planning studies, 13(1), 157-174.

Fung, A., \& Wright, E. O. (2001). Deepening Democracy: Innovations in Empowered Participatory Governance. Politics \& Society, 29(1), 5-41. doi:doi:10.1177/0032329201029001002

Goldsmith, S., \& Eggers, W. D. (2003). Governing by Network: The New Shape of the Public Sector. New York, NY, UNITED STATES: Brookings Institution Press.

Hampton, G. (2005). Enhancing public participation through narrative analysis. Policy Sciences, 37(34), 261-276. doi:10.1007/s11077-005-1763-1

Hampton, G. (2009). Narrative Policy Analysis and the Integration of Public Involvement in Decision Making. Policy Sciences, 42(3), 227-242. doi:10.1007/sl

Hansson, S. O. (2010). Risk: Objective or Subjective, Facts or Valuess. Journal of Risk Research, 13(2), 231-238.

Henly-Shepard, S., Anderson, C., Burnett, K., Cox, L. J., Kittinger, J. N., \& Ka'aumoana, M. (2015). Quantifying household social resilience: a place-based approach in a rapidly transforming community. Natural Hazards, 75, 343-363. doi:10.1007/s11069-014-1328-8)

Henwood, K., Pidgeon, N., Parkhill, K., \& Simmons, P. (2010). Researching Risk: Narrative, Biography, Subjectivity. Forum: Qualitative Social Research, 11(1). Retrieved from http://www.qualitative-research.net/index.php/fqs/article/view/1438/2925

Ho, M.-C., Shaw, D., Lin, S., \& Chiu, Y.-C. (2008). How Do Disaster Characteristics Influence Risk Perception? Risk Analysis, 28(3), 635-643. doi:10.1111/j.1539-6924.2008.01040.x

ISO. (2009). Risk management - Principles and guidelines. In (Vol. ISO 31000). Geneva: International Standards Organization.

ISO. (2014). Societal security - Business continuity management systems - Requirements. In (Vol. ISO22301:2014). Geneva: International Standards Organization.

Jacobs, J. (1961). The Death and Life of Great American Cities. New York, New York: Random House.

Jones, M. D., \& McBeth, M. K. (2010). A Narrative Policy Framework: Clear Enough to Be Wrong? Policy Studies Journal, 38(2), 329-353.

Kapucu, N., \& Garayev, V. (2011). Collaborative Decision-Making in Emergency and Disaster Management. International Journal of Public Administration, , 34, 366-375.

Kapucu, N., Hawkins, C. V., \& Rivera, F. I. (2013). Emerging research in disaster resiliency and sustainability: Implications for policy and practice. In N. Kapucu, C. V. Hawkins, \& F. I. Rivera (Eds.), Disaster Resiliency: Interdisciplinary Perspectives. New York and London: Routledge.

Larkham, P. J., \& Lilley, K. D. (2012). Exhibiting the City: Planning Ideas and Public Involvement in Wartime and Early Post-War Britain. The Town Planning Review, 83(6), 647-668.

Lindell, M. K., \& Whitney, D. J. (2000). Houshold Seismic Hazard Adjustment Adoption. Risk Analysis, 20(1), 13-25.

McBeth, M. K., Shanahan, E. A., Arnell, R. J., \& Hathaway, P. L. (2007). The Intersection of Narrative Policy Analysis and Policy Change Theory. The Policy Studies Journal, 35(1), 87-108.

McComas, K., \& Shanahan, J. (1999). Telling stories about global climate change: Measuring the impact of narratives on issue cycles. Communication Research, 26(1), 30-57.

Menapace, L., Colson, G., \& Raffaelli, R. (2012). Risk Aversion, Subjective Beliefs, and Farmer Risk Management Strategies. American Journal of Agricultural Economics, 95(2), 384-389. doi:10.1093/ajae/aas107

Moreton Bay Regional Council. (2017). Moreton Bay Regional Council Road Conditions (Live). 
Paton, D. (2005). Community Resilience: Integrating Hazard Management and Community Engagement. Paper presented at the International Conference on Engaging Communities,, Brisbane.

Paton, D., Smith, L., Daly, M., \& Johnston, D. (2008). Risk perception and volcanic hazard mitigation: Individual and social perspectives. Journal of Volcanology and Geothermal Research, 172(3), 179-188. doi:http://dx.doi.org/10.1016/j.jvolgeores.2007.12.026

Purich, A., Cowan, T., Cai, W., van Rensch, P., Uotila, P., Pezza, A., .. . Perkins, S. (2014). Atmospheric and oceanic conditions associated with southern Australian heat waves: a CMIP5 analysis. Journal of Climate, 27(20), 7807-7829.

Roe, E. (1994). Narrative Policy Analysis: Theory and Practice. Maine: Duke University Press Books.

Shaw, R. (2013). Incorporating resilience of rural communities for proactive risk reduction in Shikoku, Japan. Disaster resiliency: Interdisciplinary perspectives, 207-226.

Sjöberg, L. (2000). Factors in Risk Perception. Risk Analysis, 20(1), 1-11.

State of Queensland (Department of Main Roads and Transport). (2017a). Gladstone tide gaugeNear Real-Time data

State of Queensland (Department of Main Roads and Transport). (2017b). QLD Traffic.

Tiernan, A., McGowan, J., \& Drennan, L. (2013). From Disaster to Renewal; The Centrality of Business Recovery to Community Resilience. Retrieved from Canberra: http://www.regionalaustralia.org.au/wp-content/uploads/2013/08/From-Disaster-toRenewal.pdf

Tierney, K. (2012). Foreword. In N. Kapucu, C. V. Hawkins, \& F. I. Rivera (Eds.), Disaster resiliency: Interdisciplinary perspectives (pp. xiii-xvi). New York: Routledge.

Waugh, W. (2006). Collaboration and Leadership for Effective Emergency Management. Public Administration Review, 66(2), 132-140.

Waugh, W. (2009). Mechanisms for Collaboration in Emergency Management: ICS, NIMS, and the Problem with Command and Control. In R. O'Leary \& L. B. Bingham (Eds.), The Collaborative Public Manager : New Ideas for the Twenty-First Century (pp. 157-176). Washington DC: Georgetown University Press.

Waugh, W., \& Streib, G. (2006). Collaboration and Leadership for Effective Emergency Management. Public Administration Review, 66(2), 131-140.

Wise, C. R., \& Nader, R. (2002). Organizing the Federal System for Homeland Security: Problems, Issues, and Dilemmas. Public Administration Review, 62, 44-57.

Zheng, F., Westra, S., \& Leonard, M. (2015). Opposing local precipitation extremes. Nature Climate Change, 5(5), 389-390. 